\title{
Avian influenza virus risk assessment in falconry
}

\author{
Andrea Kohls ${ }^{1 *}$, Hafez Mohamed Hafez ${ }^{1}$, Timm Harder $^{2}$, Andreas Jansen ${ }^{3}$, Peter Lierz ${ }^{4}$, Dörte Lüschow ${ }^{1}$, \\ Brunhilde Schweiger ${ }^{3}$ and Michael Lierz ${ }^{1,5}$
}

\begin{abstract}
Background: There is a continuing threat of human infections with avian influenza viruses (AIV). In this regard falconers might be a potential risk group because they have close contact to their hunting birds (raptors such as falcons and hawks) as well as their avian prey such as gulls and ducks. Both (hunting birds and prey birds) seem to be highly susceptible to some AIV strains, especially H5N1. We therefore conducted a field study to investigate AIV infections in falconers, their falconry birds as well as prey birds.

Findings: During 2 hunting seasons (2006/2007 and 2007/2008) falconers took tracheal and cloacal swabs from 1080 prey birds that were captured by their falconry birds $(n=54)$ in Germany. AIV-RNA of subtypes H6, H9, or H13 was detected in swabs of $4.1 \%$ of gulls $(n=74)$ and $3.8 \%$ of ducks $(n=53)$ using RT-PCR. The remaining 953 sampled prey birds and all falconry birds were negative. Blood samples of the falconry birds tested negative for AIV specific antibodies. Serum samples from all 43 falconers reacted positive in influenza A virus-specific ELISA, but remained negative using microneutralisation test against subtypes $\mathrm{H} 5$ and $\mathrm{H} 7$ and haemagglutination inhibition test against subtypes $\mathrm{H} 6, \mathrm{H} 9$ and $\mathrm{H} 13$.
\end{abstract}

Conclusion: Although we were able to detect AIV-RNA in samples from prey birds, the corresponding falconry birds and falconers did not become infected. Currently falconers do not seem to carry a high risk for getting infected with AIV through handling their falconry birds and their prey.

\section{Findings}

Human infections with avian influenza viruses have been reported for the subtypes $\mathrm{H} 5, \mathrm{H} 7$, and $\mathrm{H} 9$ [1]. Siembieda et al. [2] determined an eight-time higher risk for waterfowl hunters to come into contact with AIV compared to non-hunters. Dishman et al. [3] found that duck hunters were engaged in several practices that could expose them to AIV infected wildlife. Gill et al. [4] detected antibodies against AIV subtype H11 in 1 out of 39 tested waterfowl hunters. Falconers might even be at higher risk, since hunting with falconry birds represents a selective hunting style, meaning sick, easy to catch birds are caught at a higher frequency [5]. Potentially, such birds could suffer from an AIV infection [6]. Besides natural infections of free ranging birds of prey with highly pathogenic (HP) H5N1 virus [7], the first case of HP H5N1 infection in a captive falconry bird occurred in a Saker falcon in Saudi Arabia [8], followed

\footnotetext{
* Correspondence: kohls.andrea@vetmed.fu-berlin.de

${ }^{1}$ Free University of Berlin, Faculty of Veterinary Medicine, Institute of Poultry Diseases, Koenigsweg 63, 14163 Berlin, Germany Full list of author information is available at the end of the article
}

by the culling of 37 falconry birds after confirmation of H5N1 infections in 5 falcons [9]. In 2007, H5N1 was transmitted to 10 falconry birds with direct hunting contact to infected Houbara bustards [10]. The close contact of falconers to falconry birds and their prey could pose an enhanced risk of infection with AIV to the falconer. Moreover, because falconers also come into contact with human influenza virus strains, they might contribute to the development of new pandemic virus strains should there be a co-infection with human influenza viruses. To investigate the risk of AIV transmission from falconry birds and their prey to falconers and to assess falconers in Germany as a risk group, we conducted a field study to evaluate the prevalence of AIV in falconry birds and their captured prey as well as the occurrence of antibodies against several AIV subtypes in falconers. Membership figures of the largest German falconry association, "Deutscher Falkenorden" indicate approximately 1500 falconers in Germany. This figure correspond to generally all falconers, but the number of falconers who actually go hunting with raptors, and therefore might fall into a risk group, is much
C Biomed Central 
smaller and ranges about 500 to 600 falconers. Of these about only 100 - 200 are actively hunting avian prey whereas most of them are hunting small mammals like rabbits and hares. For our study, 43 active falconers provided one serum sample and took tracheal and cloacal swabs from 1080 prey birds during 2 hunting seasons (September through March 2006/2007 and 2007/2008). The geographical range covered by the falconers comprised 11 out of 16 federal German states with a focus on north-west Germany, namely the federal states Lowers Saxony and North Rhine Westphalia (51.2\% of falconers). The falconers captured the prey birds with 54 falconry birds in 14 out of 16 federal states in Germany, again with a focus on Lowers Saxony and North Rhine Westphalia (80.5\% of prey samples). Sampled prey species comprised 759 raven crows (Corvus corone corone, 70.3\%), 89 common pheasants (Phasianus colchicus, 8.2\%), 74 gulls (Laridae, 6.9\%), 59 grey partridges (Perdix perdix, 5.5\%), 53 ducks (Anatidae, 4.9\%), 31 blackbilled magpies (Pica pica, 2.9\%), 7 common wood pigeons (Columba palumbus, 0.6\%), 6 common coots (Fulica atra, 0.6\%) and 2 Egyptian geese (Alopochen aegyptiacus, $0.2 \%$ ). The falconers were instructed to take dry swab samples immediately after their falconry bird killed the prey and to keep the samples chilled during transport. Samples were sent within a period of seven days to our institute, meanwhile stored refrigerated. At our institute, the samples were stored at $-80^{\circ} \mathrm{C}$ until processed. Swabs were investigated by virus isolation in SPF embryonated chicken eggs as described by OIE [11] and by molecular methods: RNA was firstly screened for the presence of Influenza A virus RNA as described by Spackman et al. [12], using primers modified by Hoffman. In case of a positive result, samples were further characterized by real time RT-PCR for subtypes H5, H6 and $\mathrm{H} 9$ and nested RT-PCR for H7 as described by others [13-15]. Further subtyping was carried out at the Friedrich Loeffler Institute (Insel Riems, Germany) using microarray analysis [16].

AIV-RNA was detected in swabs of 5 prey birds (0.5\%): 1 juvenile common gull (Larus canus), 2 juvenile herring gulls (Larus argentatus) as well as 1 adult and 1 juvenile mallard (Anas platyrhynchos). The gulls were hunted at 3 different times in different regions by 1 falconer in the state of Lower Saxony with a Gyrfalcon (Falco rusticolus). The ducks were hunted by a falconer from the state of Lower Saxony on 2 occasions in the same region with a peregrine falcon (Falco peregrinus) (Table 1). Subtyping revealed H13N6 in the common gull, N6 in the herring gulls (Haemagglutinin subtyping failed), H3N2 in the adult mallard and a mixed infection with H3N2 and H9N2 in the juvenile mallard. Virus isolation in these samples failed. The lack of AIV-isolation despite of the detection of AIV-RNA is most likely due to the loss of viable virus under field conditions, especially in regard of the maintenance of the cold chain. Concerning the gulls the positive samples constitute $4.1 \%$ of all investigated gull samples; concerning the mallards the percentage of positive samples among all investigated duck samples equals $3.8 \%$. Since gulls and mallards are reservoir species of AIV, this finding was not surprising and is in accordance with other studies [17]. During the years 2006 to 2009, approximately 20.000 mallards and 4.000 gulls were investigated for AIV in Germany during the national AIV wild bird monitoring program. The AIV-prevalence for mallards equaled $3 \%$, the prevalence for gulls $0.3 \%$. No AIV were detected in investigated crows $(\mathrm{n}=1054)$, common pheasants $(n=1403)$, black-billed magpies $(n=523)$ or grey partridge $(\mathrm{n}=106)$ (Figures by courtesy of the AIV national reference laboratory Friedrich Loeffler Institute, Institute of Epidemiology, Wusterhausen/Dosse). Our investigation together with the results of the national AIV wild bird monitoring in Germany from 2006 to 2009 does not disclose a widespread existence of HPAIV H5N1 or other AIV in typical prey birds in Germany besides the reservoir species. The 54 investigated falconry birds comprised 28 peregrine falcons (Falco peregrinus, 51.9\%), 13 northern goshawks (Accipiter gentilis, 24.1\%), nine Harris Hawks (Parabuteo unicinctus, 16.7\%), 2 Gyrfalcons (Falco rusticolus, 3.7\%), 1 Barbary falcon (Falco pelegrinoides, 1.9\%) and 1 Lanner falcon (Falco biarmicus, 1.9\%). The investigation of 40 choanal and 37 cloacal swabs with the same methods as

Table 1 Characteristics of the avian prey birds with detection of Influenza A virus RNA in Germany

\begin{tabular}{|c|c|c|c|c|c|c|c|c|}
\hline Species & $\begin{array}{c}\text { Cloaca } \\
(\mathrm{Ct})\end{array}$ & $\begin{array}{l}\text { Trachea } \\
\text { (Ct) }\end{array}$ & Age* & $\begin{array}{c}\text { Origin } \\
\text { (Town, State) }\end{array}$ & Date & Falconry Bird & Falconer & subtype \\
\hline Common gull & $+(33.3)$ & $+(29.6)$ & Juv & Wolfenbüttel, Lower Saxony & 2006 Nov 03 & Gyrfalcon & M40 & $\mathrm{H} 13 \mathrm{~N} 6$ \\
\hline Herring gull & $+(33.2)$ & - & Juv & Wolfenbüttel, Lower Saxony & 2007 Jan 20 & Gyrfalcon & M40 & H?N6 \\
\hline Herring gull & $+(29.5)$ & $+(32.2)$ & $\mathrm{Ad}$ & Salzgitter, Lower Saxony & 2007 Feb 07 & Gyrfalcon & M40 & H?N6 \\
\hline Mallard & $+(21)$ & $+(36.3)$ & $\mathrm{Ad}$ & Lauenhagen, Lower Saxony & 2007 Oct 15 & Peregrine falcon & M50 & $\mathrm{H} 3 \mathrm{~N} 2$ \\
\hline Mallard & $+(32.6)$ & - & Juv & Lauenhagen, Lower Saxony & 2007 Oct 17 & Peregrine falcon & M50 & $\begin{array}{l}\mathrm{H} 3 \mathrm{~N} 2 \\
\mathrm{H} 9 \mathrm{~N} 2\end{array}$ \\
\hline
\end{tabular}

\footnotetext{
* Juv, juvenile; Ad, adult
} 
described before did not reveal a current infection with AIV. 51 serum samples of these birds were investigated using agar gel immunodiffusion test (AGID), a multispecies Influenza A-ELISA (Institut Pourquier, Montpellier) and haemagglutination inhibition test (HI), as described by OIE [11], against AIV subtypes H5, H7, H9 and H13. Swab and blood samples were taken immediately before the hunting season, and for the two birds with corresponding AIV positive prey, repeated after the end of the hunting season. Antibodies against AIV or the tested subtypes were not detected. Serum samples from the 43 falconers were investigated using the multispecies Influenza A-ELISA and microneutralization assay (MN) to detect antibodies against AIV and the subtypes $\mathrm{H} 5$ and $\mathrm{H} 7$ as described elsewhere [4]. In addition, serum samples from the falconers were investigated by a modified HI test using horse erythrocytes for the detection of antibodies against AIV subtypes $\mathrm{H} 9$ and H13 [18]. All serum samples tested positive using the competitive multi-species Influenza A-ELISA. No antibodies against subtypes $\mathrm{H} 5$ and $\mathrm{H} 7$ using $\mathrm{MN}$ as well as $\mathrm{H} 9$ and $\mathrm{H} 13$ using $\mathrm{HI}$ were detected.

In conclusion, we were able to show that the AIV prevalence of prey birds from falconry is generally low, both in randomly selected sampled birds from the wild bird monitoring program, and also in actually hunted prey birds. We were also able to show that falconry birds that come into contact with AIV through their prey do not necessarily become infected. A reason for this could be that in most cases falconry birds are not allowed to eat the whole prey after the hunt, but after a short time are offered an alternative prey, such as dead chicken or mice, so that the falconer can take the catch. This short duration might not be long enough for infection. Concerning free ranging raptors the risk of infection would be higher, since these usually feed on the whole prey animal and infections of carnivores feeding on $\mathrm{H} 5 \mathrm{~N} 1$ infected animals have been reported in literature $[10,19]$. We were unable to investigate 3 falconry birds, because of accidents or non-return to the falconer during the study period. According to the falconers, these birds did not show any signs of disease until the point when they resigned from the study. Thus, infection with HPAIV H5N1 for these birds seems unlikely since Lierz et al. [20] showed that falcons are highly susceptible to HPAIV H5N1. All serum samples from the falconers showed positive results using the competitive multi-species Influenza A-ELISA. Since this method detects antibodies against all influenza A viruses regardless if of avian or human origin, this result is most likely due to previous contact to human influenza A viruses of the subtypes $\mathrm{H} 1$ and $\mathrm{H} 3$ through infection or vaccination. The following investigation using microneutralization assay to detect antibodies against subtypes $\mathrm{H} 5$ and
$\mathrm{H} 7$ as well as the screening of the sera for antibodies against subtypes $\mathrm{H} 9$ and $\mathrm{H} 13$ using $\mathrm{HI}$ gave negative results. Currently falconers do not seem to carry a higher risk for getting infected with AIV through the handling of falconry birds and their prey.

\section{Acknowledgements}

We thank the German falconry association "Deutscher Falkenorden" for partial financial support of this study. Bettina Valder, Gabi Grothehenn and Ute Hopf-Guevara are thanked for technical laboratory support, Christoph Staubach for his help with the national wild bird monitoring database. Sabine Düpre is being thanked for her help with sampling the falconry birds.

The study was approved by the Ethics Commission of the Robert Koch Institute, Berlin.

\section{Author details}

${ }^{1}$ Free University of Berlin, Faculty of Veterinary Medicine, Institute of Poultry Diseases, Koenigsweg 63, 14163 Berlin, Germany. ${ }^{2}$ Friedrich-Loeffler-Institut, Federal Research Institute for Animal Health, Suedufer 10, 17493 GreifswaldInsel Riems, Germany. ${ }^{3}$ Robert Koch Institut, Nordufer 20, 13353 Berlin, Germany. ${ }^{4}$ Department of Anesthesiology and Intensive Care Medicine, Marienkrankenhaus Soest, Widumgasse 5, 59494 Soest, Germany. ${ }^{5}$ Justus Liebig University, Clinic for Birds, Reptiles, Amphibians and Fish, Frankfurter Straße 91-93, 35392 Giessen, Germany.

\section{Authors' contributions}

AK participated in study design, collected the samples, carried out the virus isolation, serology and PCR's, analyzed data and was involved in writing the manuscript. HMH participated in study design and was involved in revising the manuscript. TH carried out the microarray analysis. AJ and PL were involved in collecting the falconer's samples. DL participated in and supervised the PCR. BS was involved in and supervised the

microneutralization assay. ML participated in study design, supported sample collection and data analysis and was involved in revising the manuscript. All authors have read and given final approval of the manuscript.

\section{Competing interests}

The authors declare that they have no competing interests.

Received: 8 February 2011 Accepted: 23 April 2011

Published: 23 April 2011

\section{References}

1. Peiris JS, de Jong MD, Guan Y: Avian influenza virus (H5N1): a threat to human health. Clin Microbiol Rev 2007, 20:243-267.

2. Siembieda J, Johnson CK, Boyce W, Sandrock C, Cardona C: Risk for avian influenza virus exposure at human-wildlife interface. Emerg Infect Dis 2008, 14:1151-1153.

3. Dishman H, Stallknecht D, Cole D: Duck hunters' perceptions of risk for avian influenza, Georgia, USA. Emerg Infect Dis 2010, 16:1279-1281.

4. Gill JS, Webby R, Gilchrist MJ, Gray GC: Avian influenza among waterfowl hunters and wildlife professionals. Emerg Infect Dis 2006, 12:1284-1286.

5. Temple SA: Do predators always capture substandard individuals disproportionately from prey populations? Ecology 1987, 63:669-674.

6. Kent J, Bailey T, Silvanose CD, McKeown S, Wernery U, Kinne J, Manvell R: An outbreak of low pathogenic avian influenza in a mixed species aviculture unit in dubai in 2005. Vet Clin North Am Exot Anim Pract 2006, 9:523-531.

7. Globig A, Staubach C, Beer M, Köppen U, Fiedler W, Nieburg M, Wilking H, Starick E, Teifke JP, Werner O, Unger F, Grund C, Wolf C, Roost H, Feldhusen F, Conraths FJ, Mettenleiter TC, Harder T: Epidemiological and ornithological aspects of outbreaks of highly pathogenic avian influenza virus H5N1 of Asian lineage in wild birds in Germany, 2006 and 2007. Transbound Emerg Dis 2009, 56:57-72.

8. Samour J: Avian Influenza in Saudi falcons. Falco Newsletter 2006, 27:21.

9. Avian Influenza - Eurasia (37): Saudi-Arabia, falcon. [http://www. promedmail.org/pls/apex/f?p=2400:1001...NO::F2400_P1001_BACK_PAGE, F2400_P1001_PUB_MAIL_ID:1000,31812]. 
10. Khan OA, Shuaib MA, Rhman SS, Ismail MM, Hammad YA, Baky MH, Fusaro A, Salviato A, Cattoli G: Isolation and identification of highly pathogenic avian influenza H5N1 virus from Houbara bustards (Chlamydotis undulata macqueenii) and contact falcons. Avian Pathol 2009, 38:35-39.

11. Avian Influenza. In: Manual of Diagnostic Tests and Vaccines for Terrestrial Animals. 2009 [http://www.oie.int/eng/normes/mmanual/ A_summry.htm]

12. Spackman E, Senne DA, Myers TJ, Bulaga LL, Garber LP, Perdue ML, Lohman K, Daum LT, Suarez DL: Development of a real-time reverse transcriptase $\mathrm{PCR}$ assay for type A influenza virus and the avian $\mathrm{H} 5$ and H7 hemagglutinin subtypes. J Clin Microbiol 2002, 40:3256-3260.

13. Slomka MJ, Pavlidis T, Banks J, Shell W, McNally A, Essen S, Brown I: Validated $\mathrm{H} 5$ Eurasian real-time reverse transcriptase-polymerase chain reaction and its application in H5N1 outbreaks in 2005-2006. Avian Dis 2007, 51:373-377.

14. Das A, Suarez DL: Development and bench validation of real-time reverse transcription polymerase chain reaction protocols for rapid detection of the sub-types $\mathrm{H6}, \mathrm{H} 9$, and $\mathrm{H} 11$ of avian influenza viruses in experimental samples. J Vet Diagn Invest 2007, 19:625-634.

15. Starick E, Römer-Oberdörfer A, Werner O: Type- and subtype-specific RTPCR assays for avian influenza A viruses (AIV). J Vet Med B Infect Dis Vet Public Health 2000, 47:295-301.

16. Gall A, Hoffmann B, Harder T, Grund C, Höper D, Beer M: Design and validation of a microarray for detection, hemagglutinin subtyping, and pathotyping of avian influenza viruses. J Clin Microbiol 2009, 47:327-334.

17. Olsen B, Munster VJ, Wallensten A, Waldenström J, Osterhaus AD, Fouchier RA: Global patterns of influenza a virus in wild birds. Science 2006, 312:384-388.

18. Kayali G, Setterquist SF, Capuano AW, Myers KP, Gill JS, Gray GC: Testing human sera for antibodies against avian influenza viruses: horse RBC hemagglutination inhibition vs. microneutralization assays. J Clin Virol 2008, 43:73-78.

19. Keawcharoen J, Oraveerakul K, Kuiken T, Fouchier RA, Amonsin A, Payungporn S, Noppornpanth S, Wattanodorn S, Theambooniers A, Tantilertcharoen R, Pattanarangsan R, Arya N, Ratanakorn P, Osterhaus DM, Poovorawan Y: Avian influenza in tigers and leopards. Emerg Infect Dis 2004, 10:2189-2191.

20. Lierz M, Hafez HM, Klopfleisch R, Lüschow D, Prusas C, Teifke JP, Rudolf M, Grund C, Kalthoff D, Mettenleiter T, Beer M, Hardert T: Protection and virus shedding of falcons vaccinated against highly pathogenic avian influenza A virus (H5N1). Emerg Infect Dis 2007, 13:1667-1674.

doi:10.1186/1743-422X-8-187

Cite this article as: Kohls et al:: Avian influenza virus risk assessment in falconry. Virology Journal 2011 8:187.

\section{Submit your next manuscript to BioMed Central and take full advantage of:}

- Convenient online submission

- Thorough peer review

- No space constraints or color figure charges

- Immediate publication on acceptance

- Inclusion in PubMed, CAS, Scopus and Google Scholar

- Research which is freely available for redistribution

Submit your manuscript at www.biomedcentral.com/submit
Biomed Central 